\title{
The effectiveness of information service with quantum learning models using music to improve student learning
}

\author{
Rahmat Wahyudi ${ }^{1}$, Neviyarni ${ }^{2}$, Agus Irianto ${ }^{3}$ \\ ${ }^{123}$ Universitas Negeri Padang
}

\begin{tabular}{l}
\hline \hline Article Info \\
\hline Article history: \\
Received Jun $07^{\text {th }}, 2019$ \\
Revised Jun $20^{\text {th }}, 2019$ \\
Accepted Jul $10^{\text {th }}, 2019$ \\
\hline
\end{tabular}

\section{Keyword:}

Learning Motivation Information Service Quantum Learning

\begin{abstract}
This research is motivated by still found learners who have no motivation to learn. One of the efforts made to improve learners' motivation is in learning by giving information service. This study aims to examine the effectiveness of information services with quantum learning model using music to improve learners' motivation is in learning. This research uses quasi experiment, with quasi experiment form is non-equivalent control group design or nonrandomized pretest-posttest control group design. The subjects of this study are the learners'of Islamic Senior High School 1 Payakumbuh as a group of experiments and the learners' of Islamic Senior High School 2 Payakumbuh as a control group. The research instrument used is Likert Scale model, then will be analyzed using Paired Samples t-test and Independent Samples Test with SPSS version 20.00. The result of the research shows that: (1) there is a significant difference of learning motivation of the students in the experimental group before and after being given information service with quantum learning model using music; (2) there is a difference of learning motivation learners' in control group before and after given information service without a quantum learning model using music, and (3) there is a difference learning motivation learners' between the experimental group provided with information service with quantum learning model using music and control group given information service without quantum learning model using music.
\end{abstract}

(C) 2018 The Authors. Published by Redwhitepress.

This is an open access article under the CC BY-NC-SA license

(https://creativecommons.org/licenses/by-nc-sa/4.0/

\section{Corresponding Author:}

Rahmat Wahyudi

Universitas Negeri Padang

Email: rahmatwahyudi488@gmail.com

\section{Introduction}

The learning process through which the learners are expected to run smoothly, for it required the existence of motivation, with the motivation is expected learners become more enthusiasm in undergoing the learning process. The phenomenon that occurs still found problems learners learn motivation. As research Kusumaningrum (2012) in high school in Karanganyar city found the learners who have low motivation problems. Furthermore, in the Sunadi (2012) study, the poor result of the students' learning on the subject of Economics is caused by low learning motivation, and the complete learning facilities are not well utilized by the students of XI Sosial Sciences class in Senior High School Muhammadiyah 2 Surabaya.

Based on the phenomena that researchers encountered in Islamic Senior High School 1 Payakumbuh and in Islamic Senior High School 2 Payakumbuh, data in the second semester of the academic, during the learning process took place many learners who have no motivation in learning. As stated by some subject teachers, homeroom teacher, student representative who was interviewed on Wednesday, May 31, 2017 found the phenomenon that: (1) students are less attention to the lesson (2) learners are not eager to do the task, 3) learners are easily desperate, (4) tasks given by teachers not done, (5) learners easy to feel bored in learning, 
The effectiveness of information service with quantum learning models using music to improve student learning

and (6) learners do not seem to have desire to excel, (7) and the pleasure of learners when given a task by the teacher.

These conditions need to be a concern for Counselors in overcoming the problem of lack of learning motivation, so that learners have high learning motivation. According to Sudjana (2014) the indicators of student's learning motivation are: (1) student's attention to the lesson, (2) the spirit of the students to do the learning tasks, (3) the responsibility in doing the learning tasks, (4) against the stimulus provided by the teacher, and (5) feeling happy and satisfied in doing the task given.

Guidance and counseling as one element in education has a very important role in improving motivation learners learners. According Prayitno (2013: 85) guidance and counseling (or called counseling) is. support services by professionals to a person or group of individuals for the development of effective daily life, and the handling of daily effective lives disrupted by an independent personal focus, capable of self-control through the organization, various services and support activities in the learning process .

Based on the definition of counseling above, it can be understood that counseling as one form of learning process is very necessary for learners. One type of service in guidance and counseling is information services. According to Prayitno (2004: 45) information service is a service provided by the counselor to the client in an effort to meet the individual lack of information required, to the service participants delivered various information, this information is then processed and used by individuals for the benefit of life and its development. Information services become one of counseling services that can foster motivation learners learners, through the material information service then it is hoped learners can understand so important motivation in learning.

Discussion of motivation to learn can be one of the material on information services, of course, Counselor before submitting materials to improve motivation to learn should be able to make learners motivated to follow the process of information services, because the method or way Counselors in providing materials can also generate motivation and enthusiasm for learning in learners. One way that can be done by a Counselor in providing information services so that learners are more interested is to utilize learning models that attract the attention of learners, the most appropriate learning to attract the attention of learners so that has the motivation is quantum learning. Kosasih \& Sumarna (2013: 89) describes the quantum learning as follows.

Quantum learning is one of the innovative learning models that are oriented towards the students (student center). Quantum learning is focused on dynamic relationships within the classroom environment with the interactions that form the foundation and framework for learning. This learning model emphasizes activities on the development of human potential optimally through very humane ways, which are easy, fun, and empowering. Based on the above description, it can be understood that quantum learning as one of the innovative learning model, can develop the potential of learners. This learning model will make learners feel learning is not something difficult, but will make learners feel happy that will increase motivation in learning.

In line with the previous description, the quantum learning model can be utilized by the teacher in the learning process, to improve the motivation of learners, such as research conducted by Kusumawardani (2016) that the application of quantum learning can improve students' learning motivation on PKN subjects. Similarly, the results of research Yustina (2009) states that the application of mind mapping techniques in quantum learning strategies can improve the motivation of learners on biology subjects. Another study also conducted by Turnip \& Panjaitan (2014) found that quantum learning model can be used to improve learning outcomes in learners. Similarly, other research also conducted by Hidayat (2010) found that the quantum learning model can be utilized to increase student value in the course of Nahwu I.

The quantum learning model uses a way that attracts the attention of learners, for example, by adding elements of music while learners are following the information service process. As Kosasih \& Sumarna (2013: 80) explained "The model of quantum learning is synonymous with a symphony and musical performance. That is, the learning of quantum learning empowers all potential and existing learning environments, so the learning process becomes a fun and not a burdensome one. "

Based on the above description, it can be understood that the quantum learning model will increase the spirit of learners in following information services. Counselor can add elements of music in the implementation of the service. Research Hari Martopo (2005) found that, music as an important factor in the application of learning methods of quantum learning.

Music can be utilized in the learning process, as Jalaludin (2005: 40) states that "Music soothes the mind and body, new research proves what parents have long suspected music can make children more calm, and therefore more intelligent". Thus, the music is expected to be used as an alternative to make students learn quietly and the learning process becomes more effective.

Meanwhile, research conducted by Sukmayadi (2014) that "Contemporary music can be used as a medium of learning". Furthermore, Susanti's research (2011) "The effectiveness of classical music in reducing mathematical anxiety (Math Anxiety) in class XI students". Different studies were also conducted by Saepudin (without years), found the result that the background music media can improve the positive emotions of 
learners on the learning of Islamic Education in Senior High School 1 Ciledug Cirebon. Some examples of the above research, it can be understood that music today can be used in the learning process. Through music learners will feel learning more calm and fun.

Tomlinson (in Ludovico \& Margione, 2014) suggests that the learning process in learners can be augmented with music, research results that the child's experience is faster when they are able to find lists or charts to communicate a new meaning that helps to make learners stronger, comfortable, passionate, creative in learning and communicating. Many things can be done by Counselors to improve motivation learners especially in the implementation of information services. Utilizing the quantum learning model requires Counselors to create a conducive learning situation for active and non-bored learners, using music during the information service implementation process.

\section{Method}

This research uses quasi experiment, with quasi experiment form is non-equivalent control group design or non-randomized pretest-posttest control group design. The subject of this study are students of class XI IIS 1 Islamic Senior High School 1 Payakumbuh and XI IIS 3 Islamic Senior High School 2 Payakumbuh Academic Year 2016/2017 with a total of 43 people. Withdrawal of research subjects by purposive sampling. The instrument is learning motivation used in this research is Likert scale. the results of reliability to motivation to learn for 0.873 . Sudijono (2011) proposed that the correlation coefficient equal to or greater than 0.70 means that the instrument is declared to be reliable. then will be analyzed using Paired Samples t-test and Independent Samples Test with SPSS version 20.00 .

\section{Results and Discussions}

Research data obtained in the experimental group based on the instruments that have been given to the 21 participants of the experimental group before the treatment (pretest) and after the treatment (posttest).

The results of the study found that motivation learners experimental group experienced changes or improvement after being given information services with quantum learning model using music. Before being given information service with quantum learning model using music, the average pretest score of 84.1429 and is in the medium category. Furthermore, after being given information service with quantum learning model using music the average posttest score increased to equal to 105.62 and is in high category.

The results of the research data obtained in the control group based on the instruments that have been given to 22 control group participants before treatment (pretest) and after treatment (posttest).

The results of the study found that the motivation of learning control group learners experience changes or improvements after being given information services without a quantum learning model using music. Prior to being given information services without a quantum learning model using music, the average pretest score of 84.6364 and is in the medium category. Furthermore, after being given information services without the quantum learning model using the average music posttest score increased to amounted to 97.45 and was in the high category. The resulting increase in the control group was lower than the experimental group and had an average difference of 12.82 .

Testing Analysis Requirements

Test requirements analysis conducted in this study is the normality test, and homogeneity test.

Normality test

Test normality by using kolpogov smirnov method indicate that data of research variable is normal distribution. In the pretest group of experiments obtained P-value of 0.416 , the experimental posttest group obtained obtained P-value of 0.994, pretest control group obtained obtained P-value of 0.873 , and group control posttest obtained obtained P-value of 0.972 . the four groups are normally distributed because they have P-value greater than the 0.05 significance level.

Homogeneity Test

Homogeneity test results show that the value of P-value is greater than the level of significance 0.05 that is equal to 0.787 . The data that is compared is pretest data in each group. Thus, it can be said that the comparable group data is homogeneous because it has a $\mathrm{P}$-value greater than the 0.05 significance level.

Hypothesis Testing

First Hypothesis Testing is Pretest Differences and Prosttest Motivation Learning Experiment Group

Hypothesis testing is done by Paired Samples t-test. To analyze the results of research, researchers used the help program SPSS version 20.00. The calculation results for the first hypothesis can be seen in table 1 below.

Tabel 1. Results Paired Sample t-test Differences Motivation Analysis in Pretest and Posttest Experiment Group 
The effectiveness of information service with quantum learning models using music to improve student learning

\begin{tabular}{|c|c|c|c|c|c|c|}
\hline \multicolumn{7}{|c|}{ Paired Differences } \\
\hline & & Mean & Std. Deviation & $\mathrm{T}$ & $\mathrm{df}$ & Sig. (2-tailed) \\
\hline $\begin{array}{l}\text { Learning } \\
\text { Motivation }\end{array}$ & Poeks-preeks & 21.476 & 11.272 & 8.731 & 20 & .000 \\
\hline
\end{tabular}

According to Table 1, the average difference between the experimental groups before and after treatment was 21.476 with Asymp. Sig. (2-tailed) of 0.000. The hypothesis is accepted when P-value is smaller than the 0.05 significance level. From the calculation results obtained the value of P-value is smaller than the level of significance $0.05(0.000<0.05)$, so $\mathrm{H} 0$ rejected and $\mathrm{H} 1$ accepted

Second Hypothesis Testing is Pretest and Posttest Differences Motivation Learning Group Control

Hypothesis testing is done by Paired Samples t-test. To analyze the results of research, researchers used the help program SPSS version 20.00. The results of the calculation for the second hypothesis can be seen in the following table. Based on the above, we get the result of the calculation as summarized in Table 2. The test of this hypothesis is done by Paired Samples t-test. To analyze the results of research, researchers used the help program SPSS version 20.00. The results of the calculation for the second hypothesis can be seen in the following table. Based on the above, the calculation results are summarized in Table 2.

Tabel 2. Results Analysis Paired Sample t-test Motivation Differences Learning in Pretest and Posttest Control Groups

\begin{tabular}{|c|c|c|c|c|c|c|}
\hline & & \multicolumn{5}{|l|}{ Paired Differences } \\
\hline & & Mean & $\begin{array}{c}\text { Std. } \\
\text { Deviation }\end{array}$ & $\mathrm{T}$ & $\mathrm{df}$ & Sig. (2-tailed) \\
\hline Motivasi Belajar & $\begin{array}{l}\text { Pos kon-pre } \\
\text { kon }\end{array}$ & 12.818 & 6.337 & 9.488 & 21 & .000 \\
\hline
\end{tabular}

According to Table 2, the average difference between the control groups before and after treatment was 12.818 with Asymp. Sig. (2-tailed) of 0.000 . The hypothesis is accepted when P-value is smaller than the 0.05 significance level. From the calculation results obtained the value of P-value is smaller than the level of significance $0.05(0.000<0.05)$, so $\mathrm{H} 0$ rejected and $\mathrm{H} 1$ accepted.

Third Hypothesis Testing That Difference Posttest Motivation Learning Students Experiment Group and Control Group

Hypothesis testing is done by Hypothesis testing is done by Independent Samples Test technique. To analyze the results of research, using SPSS version 20.00. The calculation of the results in Table 3.

\begin{tabular}{|c|c|c|c|c|c|c|}
\hline & \multicolumn{3}{|c|}{$\begin{array}{c}\text { Levene's Test for } \\
\text { Equality of } \\
\text { Variances } \\
\end{array}$} & \multicolumn{3}{|c|}{ t-test for Equality of Means } \\
\hline & $\mathrm{F}$ & Sig. & $\mathrm{T}$ & Df & Sig. (2-tailed) & Mean Difference \\
\hline Equal variances assumed & 4.472 & .041 & 3.462 & 41 & .001 & 8.165 \\
\hline
\end{tabular}

Based on Table 3, the coefficient of tcount is 3,462 with P-value 0.001. The hypothesis is accepted when $\mathrm{P}$-value is smaller than the 0.05 significance level. From the calculation results obtained $\mathrm{P}$-value value is smaller than the level of significance $0.05(0.001<0.05)$.

DISCUSSION

The findings of the study were significant differences in learning motivation of the experimental group participants with the control group. Furthermore, to further understand conceptually the results of research, then conducted a discussion of the results of research.

Motivation Learners

The results showed that the average pretest score of learning motivation in each experimental and control group were both in medium category or in the same category.

In the experimental group, the treatment provided was information service with quantum learning model using music, while in the control group was given information service without quantum learning model using music. After each group is given treatment, the motivation learners learn to increase. Based on the results of these calculations, the learning motivation of each group is in the high category. 
The quantum learning model can also be used in other subjects, such as the results of other experimental studies related to quantum learning, indicating that there is a difference between the experimental group and the control group on the learning achievement of learners using the learning model of quantum learning with ordinary learning process without using the model quantum learning (Muchlisin, 2004).

Music plays an important role in the implementation of information services with the quantum learning model, with the music is expected to become a vibrant and active learners. As explained by Andrea, recent research results emphasize that the importance of an educator to understand the desires that make learners a passion in learning, and one of them through music, (Andrea, 2014). Signed with that, a study conducted by Gouzeasis states that through music educators and learners alike can make the class more fun, (Gouzeasis, 2014). The use of music in the learning process has also been conducted abroad, as research conducted by Joseph states that in the Australian State music is an important part in formal education, not only placed as extracurricular activities but also can be utilized for the learning process (Joseph, 2015 ).

Based on the above explanation, it can be concluded that information service with quantum learning model using music can increase learners' motivation, as well as information service without quantum learning model using music, but the increase is not as big as information service with quantum learning model using music, thus it can be understood that there are significant differences in learning motivation of experimental group learners before and after being given information service treatment with quantum learning model using music.

Differences Motivation Learners Learned in Experiment Group (Pretest and Posttest)

Learning motivation in this research is the attention of learners to the lesson, the spirit of learners to do their duties, responsibilities, reaction to the stimulus provided by the teacher, and the feeling of pleasure and satisfaction in doing the task given. Information services provided are expected to help learners to foster motivation as described above, it is obtained through information services with quantum learning model using music.

Based on the results of testing the first hypothesis that reads "There is a significant difference motivation learners experimental group of experiments before and after given the treatment of information services with quantum learning model using music".

This is in accordance with the assumptions of researchers who argue that the motivation learners learn can be improved with information services with the quantum learning model using music. Provision of these services can improve the score of significant learning motivation changes in learners. At the time of the launch of the service activities, the material provided along with the music so that learners become interested and active in the learning process. In line with research conducted by Tirtoni which explains that the quantum learning model can improve the spirit and motivation of learners learners, with the accompaniment of music that characterizes the quantum learning, (Tirtoni, 2015).

The quantum learning model using music is carried out in several steps, beginning with the teacher of BK / Counselor invites, guides and motivates the learners to start the information service activities by suggesting the atmosphere of events related to service materials or called Ambak Strength, then structuring the learning environment with how to play music related to the information service material provided. Next, ask the students' responses related to the given material, give praise, familiarize the learners to record and read, and develop the creativity of learners.

Based on the research data described earlier, it can be understood that the results of research to see motivation learners experimental group (pretest and posttest) provided through information services with the quantum learning model using the music has increased. That is, there are significant differences in learning motivation of experimental group learners, before and after follow information service with quantum learning model using music. This indicates that the implementation of information services with the quantum learning model using music can be given by the Counselor to improve motivation learners learners.

Differences Motivation Learners Learners in Control Groups (Pretest and Posttest)

Efforts made in improving learning motivation learners in addition to information services with quantum learning model using music, is also done through information services without a quantum learning model using music. Based on the results of the second hypothesis testing that reads "There is a significant difference in learning motivation of control group learners before and after being given information service treatment without quantum learning model using music".

Based on the results of the study showed that the motivation score of learners of the control group before being given treatment is different from the learning motivation of the students after being given treatment. This happens because at the time of the implementation of information services, learners just listen and give a simple response about the material discussed. The increase occurs because learners gain a new understanding of the subject matter but higher increases in the experimental group.

Information services in improving the motivation of learning control group learners are given through one of the techniques in information services, namely lecture and question and answer techniques. 
The effectiveness of information service with quantum learning models using music to improve student learning

Techniques that can be used in the implementation of information services include: (a) lectures, question and answer, and discussion, (b) through media, (c) special events, and (d) resource persons (Tohirin, 2015).

Information services implemented to the control group can improve the motivation of learners, but increased learning motivation is higher for experimental group with quantum learning model using music. It is assumed that by using the model learners gain a direct understanding of the results of the service.

Differences Motivation Learning Students Experiment Group and Control Group (Pretest and Posttest)

The results showed that there was a difference between the experimental group that provided the information service with the quantum learning model using the music with the control group given information service without the quantum learning model using music.

This can be seen from the average posttest of the experimental group and the control group, clearly the difference in posttest results from each group. Thus it can be concluded that there is a significant difference motivation learners experimental group and control group. Both research groups were given the same service ie information service, but in experimental group with quantum learning model using music and in control group was given information service without quantum learning model using music.

Based on the implementation of information services with quantum learning model using music, in the experimental group of learners more active in following service activities, it is seen from the seriousness of the learners. Furthermore, learners are able to understand the material delivered with songs that are easy to memorize. In contrast to the control group, researchers only provide ordinary information services so that learners less actively convey the results of their understanding, this is in accordance with that described by Prayitno that the information service is a service BK that helps learners receive and understand various information self, social, learning, career / position, and further education in an objective, objective, and prudent direction Prayitno (2013). Furthermore, information services are meaningful as efforts to equip learners with knowledge and understanding of their environment and on the process of youth development, Tohirin (2008).

\section{Conclusions}

Based on the results of the research, and after performing statistical analysis and hypothesis testing, it can be concluded in general that information service with quantum learning model using music can improve learners' motivation rather than information service without quantum learning model using music. Specifically, the findings of this study are as follows. There is a significant difference in learning motivation of experimental group learners, before and after follow information service with quantum learning model using music, thus making learners become passion and active during follow the process of information service with quantum learning model using music. There is difference of learning motivation of control group learners, before and after follow information service without quantum learning model using music, so some learners become passion and active during follow process of information service without quantum learning model using music. There is a difference of learning motivation of experimental group learners who are given information service with quantum learning model using music with control group learners who are given information service without quantum learning model using music. In the categorization of learning motivation learners experimental groups and control groups are both in the high category, but the average greater increase occurred in the experimental group.

\section{Acknowledgments}

Allhamdulillah this research can be completed well, although there are still many shortcomings. Researchers hope that this research can be useful for the development of science, especially in the field of guidance and counseling. Researchers would like to thank all parties who have assisted in the completion of research on the effectiveness of information services with the quantum learning model using music to improve learners' motivation.

\section{References}

Gouzouasis, P., Bakan, D., Ryu, J. Y., Ballam, H., Murphy, D., Ihnatovych, D., ... \& Yanko, M. (2014). Where do teachers and learners stand in music education research? a multi-voiced call for a new ethos of music education research. International Journal of Education \& the Art, 15(15).

Hidayat. (2010). Keefektifan Pendekatan Quantum Learning dalam Peningkatan Nilai Mata Kuliah Nahwu I. Jurnal Saung Guru, 1(2).

Irianto, A. (2010). Statistik Konsep Dasar, Aplikasi dan Pengembangan. Jakarta:Kencana Joseph, D. (2015). Music Teaching and Learning In Higher Education. Journal International, 2(1):1.

Kosasih, N., \& Sumarna, D. (2013). Pembelajaran Quantum dan Optimalisasi Kecerdasan. Bandung: Alfabeta. 
Kusumaningrum, T. N. (2012). Penerapan Pembelajaran Kooperatif Tipe Student Teams Achievement Division (Stad) untuk Meningkatkan Motivasi dan Hasil Belajar Sosiologi Pada Siswa Kelas XI IPS 4 SMA Negeri Colomadu Karangayar Tahun Pelajaran 2011/2012. Sosialitas, 2(1).

Kusumawardani, I. (2016). Penerapan Quantum Learning untuk Meningkatkan Motivasi Belajar Siswa Pelajaran PKN. Basic Education, 5(20), 1-923.

Ludovico, L. A., \& Mangione, G. R. (2014). Self Relulation Competence In Music Education. International Association for Development of the Information Society.

Martopo, H. (2005). Musik Sebagai Faktor Penting dalam Penerapan Metode Pembelajaran Quantum Learninng (Music as Important Factor in Application Quantum Learning Method). Harmonia: Journal of Arts Research and Education, 6(2).

Muchlisin, F. (2014). Pengaruh Metode Pembelajaran Quantum Learning dengan Pendekatan Peta Pikiran (Mind Mapping) Terhadap Prestasi Siswa Pada Mata Pelajaran Teknologi Motor Diesel di Smk Muhammadiyah 3 Yogyakarta (Doctoral dissertation, UNY).

Prayitno, E. A., \& Amti, E. (2004). Dasar-dasar bimbingan dan konseling. Jakarta: Rineka Cipta.

Prayitno. (2004). Seri Layanan LI-L9. Padang: UNP Press.

Prayitno. (2012). Seri Panduan Layanan dan Kegiatan Pendukung Konseling. Padang: UNP Press.

Rakhmat, J. (2005). Belajar Cerdas. Bandung: MLC.

Sudjana, N. (2014). Penilaian Hasil Proses Belajar Mengajar. Bandung: Remaja Rosdakarya.

Sukmadinata, N. S. (2007). Bimbingan Konseling dalam Praktek. Jakarta: Maestro.

Sukmayadi, Y. (2014). Musik Kontemporer dalam Kurikulum dan Buku Sekolah di Jerman. Resital: Jurnal Seni Perteunjukan, 15(2).

Tirtoni, F. (2015). Penerapan Metode Quantum Learning Berkarakter Pada Pembelajaran Pendidikan Kewarganegaraan (PKN). Jurnal Pedagogia, 1(4):1.

Tohirin. (2015). Bimbingan dan Konseling di Sekolah dan Madrasah (Berbasis Integrasi). Jakarta. Rajawali Pers. 